\title{
A 7 ÉS 15 ÉVES VAK GYERMEKEK EMLÉKEZETI, NYELVI ÉS TÉRI FELDOLGOZÁS MUTATÓI
}

\author{
PAJOR EMESE ${ }^{1}$ - BEKE ANNA MÁRIA² - CSÉPE VALÉRIA ${ }^{3}$ \\ ${ }^{1}$ ELTE Bárczi Gusztáv Gyógypedagógiai Kar \\ ${ }^{2}$ Semmelweis Egyetem I. Sz. Szülészeti és Nôgyógyászati Klinika \\ ${ }^{3}$ MTA TTK Agyi Képalkotó Központ \\ E-mail: emese.pajor@gmail.com
}

Beérkezett: 2014. március 11. - Elfogadva: 2016. április 10.

\begin{abstract}
A látássérült populáció kognitív vizsgálata mérésmetodikai problémák miatt nehézségbe ütközik. Ez kifejezetten érvényes a vak gyermekek mérésére. Tanulmányunk célja a korábban és jelenleg is használt populációspecifikus tesztbattériák bemutatása, majd az általunk kialakitott és pszichometriai elemzésnek alávetett feladatsor használatával felmért 7-15 éves teljes magyar ép értelmú vak populáció és illesztett látó kontrollcsoport kognitív profiljának elemzése. A feladatok megválasztási szempontjainál mérlegelésre kerültek a jelenlegi intelligenciakutatások által megerösitett föbb dimenziók, az alkalmazhatóság és a tesztek elérhetôsége. A kiválasztott vagy kialakított feladatok magját a NEPSY®-I és a WISC-IV tesztek elméleti és gyakorlati tapasztalatai adták. Eredményeink közül kiemelendô, hogy a vak csoport a téri feldolgozás területén nagymértékú elmaradást mutat a látó kontrollhoz képest. A látó mintában a koraszülött gyermekek a téri feladatok esetén rosszabbul teljesitenek idốre született társaikhoz képest. A vak és a látó csoportok a munkamemória feladatok közül csak a Magyar Álszóismétlési Teszt (Racsmány és mtsai, 2005) esetén mutattak szignifikáns különbséget, továbbá, a két csoport eredménye a fonéma fluenciát mérö feladatban tért el egymástól. Eredményeink alapján elmondható, hogy a vakság nagymértékben befolyásolja a téri tájékozódást, azonban a verbális munkamemóriát és a nyelvi funkciókat kevésbé.
\end{abstract}

Kulcsszavak: vakság, kognitív profil, mérésmetodikai kérdések 


\section{BEVEZETÉS}

\section{Mérésmetodikai problémák és kérdések}

A látássérült ${ }^{1}$ populáció kognitív vizsgálati eredményének reliabilitása és validitása több esetben megkérdôjelezhetô, mivel a vizsgálatukra is használt tipikus fejlôdésre kidolgozott kognitív és neuropszichológiai tesztek vizuális feladatokat is tartalmaznak. A csupán verbális feladatokkal való mérési eredmény sem reális, mivel egyrészrôl az intelligenciafogalom leszúkítését vonja magával (Prónay, 2004), másfelól a látássérült személyek szignifikánsan alacsonyabb pontszámot érnek el a kognitív teszteken a látókhoz képest, mely különösen a kortikális látássérült személyek (CVI) esetén tapasztalható (Bertone, Bettinelli és Faubert, 2007; Ek, Jacobson, Ygge, Fellenius és Flodmark, 2000).

Az alacsony incidencia problémája mellett további nehézség a látássérült - ezen belül a vak - populáció heterogenitása, valamint a homogén életkori csoportok kialakítása és kontrollcsoportokkal történô összehasonlíthatósága. A látássérült személyek neuropszichológiai vizsgálatakor továbbá figyelembe kell venni a populáció heterogenitását alakító faktorokat, úgymint a látássérülés etiológiáját, a látássérülés kezdetének idejét, a vizuális funkció mértékét, melyek kontroll alatt tartásával a teszteredmények pontossága növelhetô (Dial és Dial, 2010).

Látássérült gyermekek esetén a látókhoz képest nagyobb a zavart vagy sérült funkciók kialakulásának esélye (Dial és Dial, 2010). A sztenderdizált teszteket elsôsorban ép érzékszervekkel rendelkezô gyermekek részére alakították ki. Érzékszervi fogyatékosság esetén, a tesztfelvétel során vagy kizárnak bizonyos szubteszteket, vagy apróbb változtatásokat iktatnak be, amelyek módosítják az eredményeket, így a pontszámok vesztenek a reliabilitásukból, validitásukból, és így megkérdőjeleződik, hogy ilyen módon valóban az adott kognitív funkció tesztelése történik-e (Roid, 2003; Sattler és Dumont, 2004). A klinikai tapasztalatok szerint a teszteken elért eredmények alapján az érzékszervi fogyatékos gyermekek képességei is „alulmértek” (Driver és Warschausky, 2010).

Összességében elmondható tehát, hogy a látássérült gyermekek szórt képességprofilja mögött nem feltétlenül a populáció gyengeségei és erôsségei állnak (Ek és mtsai, 2000), hanem mérésmetodikai nehézségek, úgymint a teljes tesztbatéria helyett csupán az egyes szubtesztek használata, vagy a pszichometriai kritériumoknak nem megfelelő tesztadaptáció.

\section{A méröeszközökröl}

Vak, illetve súlyos fokban látássérült gyermekek és felnôttek esetében elôtérbe kerülnek a szenzoros diszkriminációt mérô taktilis tesztek, feladatok, mivel a taktilis feldolgozás összefügg a kognitív funkciókkal, továbbá a taktilis-kognitív kapcsolat ereje megfeleltethetố az auditív-kognitív és a vizuális-kognitív kapcsolatok erôsségének (Li, Jordanova és Lindenberger, 1998). A szenzoros diszkrimináció mérésére mind a látó, mind a

${ }^{1}$ Látássérült: vak, aliglátó, gyengénlátó személyek összessége. 
látássérült populáció esetében elterjedt vizsgálati eszközök a Roughness Discrimination Test (Nolan és mtsai, 1965), a Boehm Test of Basic Concepts (Boehm, 1971), illetve a Tests of Mommers (Mommers, 1974). A feladatok lényege, a változó érdességgel rendelkezô felületek felismerése, vagy párba rendezése. A kifejezetten látássérült személyeknek kialakított tesztek közül legelterjedtebb a Haptic Sensory Discrimination Test (HSDT) (McCarron és Horn, 1979), mely funkcionális taktilis diszkriminációt és rövid távú taktilis emlékezetet mér. Szintén gyakran használt eljárás a Johnson és Phillips (1981) által kifejlesztett Grating Orientation Task (GOT), továbbá a Tactual Profile (Withagen és mtsai, 2009) feladatsor.

A látássérült személyeknél alkalmazott pszichometriai tesztek hármas felosztásban, általános intelligenciát mérô, verbális, továbbá nonverbális, taktilis, performációs tesztcsoportosításban kerülnek bemutatásra.

\section{Általános intelligenciát mérố tesztek - verbális és performációs próbákkal}

A legkorábbi, mind vak gyermekek, mind vak felnôttek körében használt, de nem számukra kifejlesztett intelligenciateszt az Interim Hayes-Binet Intelligence Scale (1942) a Stanford-Binet Intelligencia Teszt nonvizuális itemeinek felhasználásával készült. Az Interim Hayes-Binet Tesztre támaszkodva Davis (1980) alkotta meg a Perkins-Binet Tests of Intelligence for the Blind méróeszközt, mely mind verbális, mind performációs kvócienst számol. Aliglátó és vak iskoláskorú (4-18 éves) gyermekeken sztenderdizálták 1980-ban (USA). A sok negatív kritika miatt bevonták a piacról.

Látássérült személyek intelligencia mérésére kifejlesztett mérôeszköz a Vithoba Paknikars Performance Test for the Blind* (Paknikar, 1981), valamint a Cognitive Test for the Blind* (CTB) (Dial, Mezger, Gray és Chan, 1988). A CTB a kognitív funkciók közül méri az absztrakt gondolkodást, az auditív nyelvi funkciókat, az emlékezetet, a téri képességeket. Aktív problémamegoldásra, tanulásra és emlékezetre fókuszál. Verbális szubtesztjei: hallási analízis, közvetlen számismétlés, beszédértés és emlékezet, szám és betûtanulás, szókincs. Non-vizuális szubtesztjei: haptikus kategóriatanulás, haptikus kategória emlékezet, haptikus emlékezeti felismerés, minta elôhívás, téri analízis. Látássérült gyermekek és felnôttek részére egyaránt alkalmas.

Az Intelligence Test for Visually Impaired Children (ITVIC)* (Dekker, 1991) teszt, mely 6-15 éves látássérült gyermekek részére lett kidolgozva, szintén mind a verbális, mind a taktilis képességeket méri. A holland Bartimeus Intézetben fejlesztették ki, német és holland (1992), továbbá angol (1995) nyelven érhetô el. Magyar változata is létezik. ${ }^{2}$ Nagy hátránya, hogy a tesztfelvétel akár 8 órát is igénybe vehet. Verbális szubtesztjei: Számismétlés, Szókincs, Fluencia, Verbális analógiák, Névtanulás. Performációs szubtesztjei: Tárgyak észlelése, Vonal alakok észlelése, Kakukktojás, Alakos analógiák, Mozaik, Négyszög puzzle, Kérdések a térképrôl, Házalaprajz. ${ }^{3}$

\footnotetext{
${ }^{2}$ A tesztrôl bốvebben Prónay B. (2004). Vak gyermekek verbális intelligenciájának vizsgálata. Tapasztalatok a MAWGYI-R teszttel. Magyar Pszichológiai Szemle 59(1), 57-75.

${ }^{3}$ A szubtesztekrôl bốvebben: Prónay B. (2014). Az „Intelligenciateszt Látássérült Gyermekek Számára” bemutatása és egy magyar minta eredményei. Magyar Pszichológiai Szemle 69(1), 145-162.
} 
1. táblázat. Általános intelligenciát mérô tesztek - verbális és performációs próbákkal

\begin{tabular}{|c|c|c|c|}
\hline A teszt elnevezése & $\begin{array}{l}\text { Fejlesztő }(\mathrm{k}), \text { Fejlesz- } \\
\text { tés alapja }\end{array}$ & $\begin{array}{l}\text { Megjelenés } \\
\text { ideje }\end{array}$ & Validitás, korrelációk \\
\hline $\begin{array}{l}\text { Interim Hayes-Binet } \\
\text { Intelligence Scale }\end{array}$ & $\begin{array}{l}\text { Stanford-Binet Intel- } \\
\text { ligencia Teszt non- } \\
\text { vizuális itemeinek } \\
\text { felhasználásával. }\end{array}$ & 1942 & $\begin{array}{l}\text { Magasan korrelál az aka- } \\
\text { démiai teljesítményekkel. }\end{array}$ \\
\hline $\begin{array}{l}\text { Perkins-Binet Tests of } \\
\text { Intelligence for the Blind }\end{array}$ & $\begin{array}{l}\text { Davis } \\
\text { Interim Hayes-Binet } \\
\text { teszt alapján készült. }\end{array}$ & 1980 & $\begin{array}{l}\text { Alacsony korrelációt } \\
\text { mutat a WISC-R verbális } \\
\text { skáláival, a reliabilitása } \\
\text { nem elégséges. Alacsony } \\
\text { korrelációt mutat a Wide } \\
\text { Range Achievement Test } \\
\text { (WRAT)-el (Gutterman } \\
\text { és mtsai, 1985). }\end{array}$ \\
\hline $\begin{array}{l}\text { Vithoba Paknikars } \\
\text { Performance Test for the } \\
\text { Blind } *^{4}\end{array}$ & Paknikar & 1981 & \\
\hline $\begin{array}{l}\text { Cognitive Test for the Blind* } \\
\text { (CTB) }\end{array}$ & $\begin{array}{l}\text { Dial, Mezger, Gray és } \\
\text { Chan }\end{array}$ & 1988 & $\begin{array}{l}\text { Validitás } 292 \text { fó gyengén- } \\
\text { látó és vak személyen. } \\
\text { WAIS-R verbális szubteszt- } \\
\text { jeivel r=0,71. } \\
\text { Survey of Func- } \\
\text { tional Adaptive Behavior } \\
\text { (SFAB) teszttel } r=0,50 \text {. } \\
\text { Teszt-reteszt reliabilitás } \\
\text { nagyon jó: } r=0,95 \text {. }\end{array}$ \\
\hline $\begin{array}{l}\text { Intelligence Test for Visually } \\
\text { Impaired Children (ITVIC)* }\end{array}$ & Dekker & $\begin{array}{l}1989 \\
\text { más forrás } \\
\text { szerint } \\
1992\end{array}$ & $\begin{array}{l}156 \text { látássérült, Braille-t } \\
\text { olvasó hollandul beszélő, } \\
\text { holland és belga gyer- } \\
\text { meken sztenderdizálták, } \\
\text { azonban nem vették } \\
\text { figyelembe a megvakulás } \\
\text { időpontját. } 4 \text { faktort külö- } \\
\text { nítettek el. } \\
\text { Teszt-reteszt reliabilitás: } \\
\text { r=0,76-0,94 között. }\end{array}$ \\
\hline $\begin{array}{l}\text { Detroit Test of Learning } \\
\text { Aptitude (DTLA)* }\end{array}$ & & & $\begin{array}{l}\text { A pontszámok jól korre- } \\
\text { lálnak a Wechsler skálák } \\
\text { verbális szubtesztjeivel. } \\
1350 \text { látássérült gyerme- } \\
\text { ken validálták. } \\
\text { A teszt-reteszt koefficiens } \\
0,71-0,91 \text { között. }\end{array}$ \\
\hline
\end{tabular}

A Detroit Test of Learning Aptitude (DTLA)* tesztet 6-17 év közötti látássérült gyermekek számára alakították ki. A felvételi ideje 40-120 perc között változik. Három faktort, a nyelvet, a figyelmet és a percepciót méri.

\footnotetext{
${ }^{4}$ A látássérült személyek részére kialakított - és nem adaptációból készített - teszteket *-al jelöljük.
} 
A teljesítménytesztek közül a Woodcock-Johnson ${ }^{\circledR}$ teszt feladatai nagy betúméretben és Braille-ben/taktilis változatban is elérhetô az APH-n (American Printing House for the Blind) keresztül. Alacsony intelligenciaövezetben és fiatal korosztály esetén azonban nem mér megbízhatóan. A Stanford Achievement Testnek is létezik nagy betúméretû és Braille/ taktilis változata is. Ha a feladatok során nem mérünk idôt, akkor a látó és látássérült személyek átlagpontszámai megegyeznek.

\section{Verbális tesztek}

A tesztadaptációk korai megoldása a performációs feladatok teljes elhagyásával manipulált. A Wechsler-típusú tesztek verbális itemeit széles körben alkalmazták és alkalmazzák vak gyermekek intelligencia mérésére.

A WISC szubtesztjei közül jól használhatóak az Ismeretek, Általános megértés, Számolás, Közös jelentés és Szókincs feladatok. A kiegészítô tesztek helyettesíthetőek az Általános megértés, Közös jelentés szubtesztekkel, a reálisabb IQ meghatározásához. A látássérült gyermekek magasabb pontszámot érnek el a Számterjedelem és az Ismeretek feladatokban és alacsonyabbat a Közös jelentés és az Általános megértés feladatokban, mivel az utóbbi szubtesztek absztrakt fogalmakat is tartalmaznak.

Hayes-Binet Intelligence Test/Scale for the Blind (1937) elsôként adaptálta látássérült gyermekek számára a Standford-Binet Intelligencia Tesztet. Braille adaptációval rendelkezett, leginkább verbális itemeket használt. Vak gyermekeknél a WISC verbális memória szubtesztek eredményei jobbak voltak, mint a Standford-Binet eredményei (Tillman, 1973; id. Begum, 2003). Az egyetlen, Nagy-Britanniában sztenderdizált verbális intelligenciát mérô speciális intelligenciateszt a Williams Intelligence Test for Visual Impaired Children (1956). Bár nem teljesíti a modern tesztelmélet minden kívánalmát, Tobin és Hill (2011) szerint a mai napig jól használható, azonban szükséges lenne az új sztenderdizálás.

Szintén speciálisan (4-65 év közötti) látássérült személyek számára kifejlesztett verbális intelligenciát mérô eljárás a Slosson Intelligence Test (1963). Fóbb szubtesztjei: az Általános ismeretek, Hasonlóságok és különbségek, Szókincs, Általános megértés,

2. táblázat. Verbális intelligencia tesztek vak személyek részére a WISC teszt alapján

\begin{tabular}{|l|l|l|l|}
\hline A teszt elnevezése & $\begin{array}{l}\text { Fejlesztő(k), } \\
\text { Fejlesztés alapja }\end{array}$ & $\begin{array}{l}\text { Megjelenés } \\
\text { ideje }\end{array}$ & Validitás, korrelációk \\
\hline $\begin{array}{l}\text { Hayes-Binet } \\
\text { Intelligence Test/ } \\
\text { Scale for the Blind* }\end{array}$ & $\begin{array}{l}\text { Standford-Binet } \\
\text { Intelligencia Teszt } \\
\text { alapján }\end{array}$ & 1937 & \\
\hline $\begin{array}{l}\text { Williams Intelligence } \\
\text { Test for VI Children } \\
(\text { UK)* }\end{array}$ & Williams & 1956 & $\begin{array}{l}\text { Tobin és Hill (2011) teszt-reteszt } \\
\text { reliabilitást talált. }\end{array}$ \\
\hline $\begin{array}{l}\text { Slosson Intelligence } \\
\text { Test* } \\
\text { (USA) }\end{array}$ & $\begin{array}{l}\text { Slosson és } \\
\text { Nicholson }\end{array}$ & 1963 & $\begin{array}{l}\text { Validitás: } \\
\text { 234 fó 6-16 éves látássérült gyer- } \\
\text { mekkel. WISC-R teszttel szignifi- } \\
\text { káns korreláció. 10 fó látássérült } \\
\text { személlyel WAIS-R teszttel szigni- } \\
\text { fikáns korreláció. }\end{array}$ \\
\hline
\end{tabular}


Számterjedelem, Számolás, Látás-mozgás és a Hallási mondatemlékezet. Gyorsan, 20 perc alatt felvehetô.

\section{Hazai tapasztalatok a MAWGYI-R verbális próbáival vak gyermekeknél}

Prónay (2004) vizsgálata szerint a vak gyermekek (5-16 év) VQ-ja kicsit alacsonyabb, mint az azonos életkorú látóknak. A vak gyermekek szubtesztekben nyújtott teljesítménye sajátos profilt mutat. Legmagasabb teljesítményt a Számismétlés és Szókincs próbákban nyújtották, mely meghaladja a tesztben nyújtott átlagos teljesítményüket. A vakon született gyermekek eredménye jobb a késóbbi életkorban magvakultakénál, és a látó gyermekekénél. A vizsgálatban a vak gyermekek jó teljesítményt értek el a Közös jelentés szubtesztben, gyenge teljesítményt az Általános megértés és Általános ismeret próbákban és jelentôsen gyenge teljesítményt a Számolási gondolkodás szubtesztben.

\section{Nonverbális, taktilis, performációs tesztek}

A legtöbb kritikát a performációs tesztek kapták alacsony megbízhatósági mutatóik és nehézkes adminisztrációik miatt (Prónay, 2004).

A tesztadaptációk közül a performációs kvócienst mérô Stanford-Ohwaki-Kohs Tactile Block Design Intelligence Test for the Blind (1960) felvételi ideje 1-2 óra. Normalizált (USA), a percentilisek, kvóciensek megadottak, azonban a normatív adatai már nem megbízhatóak. A WAIS-R teszt néhány szubtesztje is átvételre került, de a két teszt pontszámait nem korreláltatták egymással. A feladat a 2D-ban bemutatott taktilis minta 3D-ba történó felépítése.

Iskoláskorú gyermekek részére lett kifejlesztve a The Blind Learning Aptitude Test (BLAT) $(1964,1979)$. A teszt taktilis ábrákat tartalmaz, a szimbólumok megkülönböztetésére és dedukciós következtetésekre épül, a tanulási képességet és a tanulás folyamatát elemzi, túlmutatva a merev végeredmény-centrikusságon.

A D-48 Test taktilis adaptációja (UK) a szokásos 3 dimenziós dominókból áll, és az eredeti teszt szekvenciáját követi. Bár nem mér idôt, maga a feladat - a készítôik által is bevallva - erôs frusztrációt okozhat némely vizsgálati személynél.

A Raven-progresszív mátrix alapján, 6-15 éves látássérült gyermekeknek készült a Tactual Progressive Matrices Test (1965). A taktilitását balzafa és dörzspapír felhasználásával biztosították. A magas elôállítási költsége miatt azonban nem terjedt el széles körben.

A speciálisan látássérült személyek részére kialakított tesztek közül a Haptic Memory Matching Test* (HMMT) haptikus memóriát és téri lokalizációt mér. A Haptic Test for the Blind* (2005) a perceptuális információk feldolgozását méri. A szubtesztjei taktilis vonalakat, pontokat, megszokott/ismert és szokatlan/ismeretlen háromdimenziós tárgyakat használ. A Three-Dimensional Haptic Matrix Test of Nonverbal Reasoning (3-DHM) (2007) pontszámai a non-verbális kognitív képesség valid indikátorainak bizonyultak, bár ez elsôsorban a haptikus téri gondolkodás, képesség, mintsem az általános nonverbális képesség faktorai. 
Egyéb haptikus teszteket állítottak össze halmozottan sérült vak személyek és siket-vak személyek részére. ${ }^{5}$

3. táblázat. Nonverbális, taktilis, performációs tesztek

\begin{tabular}{|c|c|c|c|}
\hline A teszt elnevezése & $\begin{array}{l}\text { Fejlesztő(k), Fejlesztés } \\
\text { alapja }\end{array}$ & $\begin{array}{l}\text { Megjelenés } \\
\text { ideje }\end{array}$ & Validitás, korrelációk \\
\hline $\begin{array}{l}\text { Stanford-Ohwaki- } \\
\text { Kohs Tactile Block De- } \\
\text { sign Intelligence Test } \\
\text { for the Blind }\end{array}$ & $\begin{array}{l}\text { Dauterman és Suinn, } \\
\text { Koh’s Block Design } \\
\text { Teszt (1923) } \\
\text { taktilis változata. }\end{array}$ & 1960 & $\begin{array}{l}\text { A WAIS Block Design szub- } \\
\text { tesztével megfeleltethetô. }\end{array}$ \\
\hline $\begin{array}{l}\text { Haptic Intelligence } \\
\text { Test }\end{array}$ & $\begin{array}{l}\text { Shurrager és Shur- } \\
\text { rager }\end{array}$ & 1964 & \\
\hline $\begin{array}{l}\text { The Blind Learning } \\
\text { Aptitude Test (BLAT) }\end{array}$ & $\begin{array}{l}\text { Néhány feladata a } \\
\text { Raven-teszt (Raven's } \\
\text { Progressive Matrices) } \\
\text { és a Culture Fair Intel- } \\
\text { ligence Test adaptá- } \\
\text { ciója. } \\
\text { Newland }\end{array}$ & 1964 és 1979 & $\begin{array}{l}\text { A teszt korrelál a Brail- } \\
\text { le-olvasási sebességgel. Az } \\
\text { USA-ban, Angliában, Wales- } \\
\text { ben és Indiában használják } \\
\text { (Mason és Skukla, 1992; id. } \\
\text { Atkins, 2012). } \\
\text { A BLAT és a szövegértés } \\
\text { között erôsebb a korreláció, } \\
\text { mint a BLAT és a Braille ol- } \\
\text { vasási sebesség között. Szin- } \\
\text { tén szignifikáns kapcsolat } \\
\text { van a WISC-R performációs } \\
\text { feladatai és a BLAT között } \\
\text { (Baker és mtsai, 1995). }\end{array}$ \\
\hline $\begin{array}{l}\text { Tactual Progressive } \\
\text { Matrices Test }\end{array}$ & $\begin{array}{l}\text { Raven-progresszív } \\
\text { mátrix teszt taktilis } \\
\text { változata. } \\
\text { Rich \& Anderson }\end{array}$ & 1965 & $\begin{array}{l}\text { Magas reliabilitás és kö- } \\
\text { zepes erósségú validitás } \\
\text { jellemzi. } 115 \text { vak gyermeken } \\
\text { mérték be. } \\
\text { A Wechsler-tesztek verbális } \\
\text { szubtesztjeivel, a tanulmá- } \\
\text { nyi eredményekkel és az } \\
\text { életkorral magasan korrelál } \\
\text { (Dauterman és mtsai, 1967; } \\
\text { id. Reid, 1997). }\end{array}$ \\
\hline $\begin{array}{l}\text { D-48 Test } \\
\text { (UK) }\end{array}$ & $\begin{array}{l}\text { D-48 taktilis verziója; } \\
\text { Gough és Domino }\end{array}$ & $\begin{array}{l}1963 \\
\text { (más forrás } \\
\text { szerint 1968) }\end{array}$ & $\begin{array}{l}\text { Az eredmények korrelálnak } \\
\text { a WISC és a WAIS verbális } \\
\text { szubtesztjeivel. } \\
\text { A középiskolás és főiskolás } \\
\text { korosztály körében felvett } \\
\text { teszt eredményei } 0,70 \text { kor- } \\
\text { relációt mutatnak. }\end{array}$ \\
\hline
\end{tabular}

${ }^{5}$ Haptic Intelligence Scale for Adult Blind* (Shurragar és Shurragar, 1974): Fôként vakon született felnốttek számára készített haptikus intelligenciateszt. Wechslerre emlékeztetô haptikus próbákat tartalmaz: Összeillesztés próba, Mozaik, Memória. Hill performance test of selected positional concepts. Curriculum guide for deaf- blind and severely multi-handicapped students (Hill, 1981). A téri fogalom fejlôdését méri. Siketvak és halmozottan fogyatékos látássérült tanulók számára is alkalmas. 
3. táblázat folyt.

\begin{tabular}{|l|l|l|l|}
\hline A teszt elnevezése & $\begin{array}{l}\text { Fejlesztó(k), Fejlesztés } \\
\text { alapja }\end{array}$ & $\begin{array}{l}\text { Megjelenés } \\
\text { ideje }\end{array}$ & Validitás, korrelációk \\
\hline $\begin{array}{l}\text { Haptic Memory Mat- } \\
\text { ching Test (HMMT * }\end{array}$ & Ballesteros és mtsai \\
\hline $\begin{array}{l}\text { Blindic Test for the } \\
\text { (Spain) }\end{array}$ & 2005 & $\begin{array}{l}\text { Összehasonlítva a vak, a } \\
\text { gyengénlátó és a látó gyer- } \\
\text { mekek eredményét, a teszt } \\
\text { magas reliabilitást mutat. }\end{array}$ \\
\hline $\begin{array}{l}\text { Three-Dimensional } \\
\text { Haptic Matrix Test of } \\
\text { Nonverbal Reasoning } \\
\text { (3-DHM) }\end{array}$ & $\begin{array}{l}\text { A Raven-progresszív } \\
\text { mátrix alapján készült. }\end{array}$ & Miller és mtsai. & $\begin{array}{l}\text { A teszt magasan korrelál a } \\
\text { Cognitive Test for the Blind } \\
\text { (CTB)-el és alacsonyan a } \\
\text { WAIS-III teszt verbális szub- } \\
\text { tesztjeivel. }\end{array}$ \\
\hline $\begin{array}{l}\text { Test of Nonverbal In- } \\
\text { telligence } \\
\text { Tactile TONI }\end{array}$ & & $\begin{array}{l}\text { A nonverbális performációs } \\
\text { teszt problémamegoldó ké- } \\
\text { pességet mér, azonban a PQ } \\
\text { értékek megkérdójelezhe- } \\
\text { tốek. A teszt bemérése 11, } \\
\text { alacsony verbális intelligen- } \\
\text { cia értéket elért, 19-50 év } \\
\text { közti, vak felnôtt személyen } \\
\text { történt. }\end{array}$ \\
\hline $\begin{array}{l}\text { Haptic Intelligence } \\
\text { Scale for Adult Blind* }\end{array}$ & $\begin{array}{l}\text { Shurragar és } \\
\text { Shurragar }\end{array}$ & 1974 & \\
\hline
\end{tabular}

\section{MÓDSZER}

\section{Célkitüzés}

Egy olyan feladatsor kialakítására törekedtünk, amely mind látó, mind látássérült személyek részére megfelelô, továbbá mind verbális, mind performációs szubteszteket tartalmaz, illetve mentes a hosszabb „rátanulási” folyamatoktól, alkalmas a vizsgált életkori intervallum mérésére, és melynek felvételi idôigénye látássérült személyek esetén is maximum $2 \times 45$ perc.

A feladatok kiválasztásakor, vagy kidolgozásakor szem elôtt tartottuk, hogy a látássérült személyek részére adaptált, vagy létrehozott tesztek sztenderdizálása komoly akadályokba ütközik. Például az USA-ban, a populáció incidenciája a sztenderdizáláshoz megfelelő, azonban a populáció területi elterjedése nem ideális (Hull és Mason, 1993). Kisebb területú országokban - akár azonos vaksági koefficiens mellett is - a populáció nagysága túl kicsi a sztenderdizáláshoz (Begum, 2003).

Feladataink a modern kognitív neuropszichológiai ismereteknek megfelelóen lettek összeállítva, figyelembe véve a látássérült populáció intellektuális képességrendszerének vizsgálatára adaptált, vagy létrehozott mérôeszközök felépítését és gyakorlati 
felhasználásukból levont tapasztalatokat. A szubtesztek magját a NEPSY ${ }^{\circledR 6}$ és a WISC ${ }^{7}$ tesztek adták, melynek elônye, mindkét teszttel kapcsolatban rendelkezünk hazai tapasztalattal, továbbá bizonyos eredményeket normákhoz is hasonlíthatunk.

A feladatsor összeállításakor szempont volt, hogy három alapterületet (emlékezet, tanulás; téri feldolgozás; nyelvi terület) vizsgáljon, vak gyermekeknek is alkalmas módon. A feladatsor kialakításának célja, hogy vak gyermekeknél az átlagos kognitív kapacitás mellett is az egyes megismerési funkciók lényeges eltéréseit képes legyen jelezni, illetve a késôbbiekben a Braille-karakterek és szavak olvasási nehézségéhez kapcsolódó háttérfunkciókat feltárni.

\section{A vizsgálati minta}

A vizsgálatban a 130 fôs vak mintát a 7-15 év közötti 85 VQ (MAWGYI-R verbális próbái alapján számolt érték ${ }^{8}$ ) feletti tanulók alkotják, mely lefedi a teljes magyar 7-15 éves ép értelmú vak populációt. A látó csoport 161 fooból áll.

4. táblázat. A vak-látó minta leíró statisztikája

\begin{tabular}{|c|c|c|c|c|c|c|c|}
\hline & \multicolumn{3}{|c|}{ Látók (N=161) } & \multicolumn{3}{|c|}{ Vakok $(\mathrm{N}=130)$} & \multirow[b]{2}{*}{$\mathrm{t}$ teszt } \\
\hline & $M$ & $S D$ & $\min -\max$ & $M$ & $S D$ & $\min -\max$ & \\
\hline $\begin{array}{l}\text { Nem (fiú:lány) } \\
(54 \%: 46 \%)\end{array}$ & $87: 74$ & & & \multicolumn{3}{|c|}{$74: 56(57 \%: 43 \%)$} & $\chi^{2}(1)=0,242, p=0,623$ \\
\hline Életkor (hónap) & 130,37 & 29,97 & $88-187$ & 133,10 & 32,63 & $86-182$ & $\mathrm{t}(289)=-0,743, \mathrm{p}=0,458$ \\
\hline VQ & 100,44 & 9,32 & $85-115$ & 97,14 & 8,74 & $85-115$ & $\mathrm{t}(289)=1,002, \mathrm{p}=0,201$ \\
\hline Gesztációs idô & 34,18 & 6,04 & $23-41$ & 33,25 & 6,24 & $24-40$ & $\mathrm{t}(289)=1,281, \mathrm{p}=0,231$ \\
\hline Születési súly & 2257,62 & 1180,59 & $610-4100$ & 2091,09 & 1169,12 & $570-3920$ & $\mathrm{t}(289)=1,201, \mathrm{p}=0,269$ \\
\hline
\end{tabular}

A vak populáción belül a koraszülött gyermekek nagyobb aránya és az illesztés jósága miatt a minta gesztációs idô alapján 4 csoportból - vak-koraszülött (VK) és vak-idôre született (VI), továbbá illesztett látó-koraszülött (LK) és látó-idôre született (LI)

${ }^{6}$ A NEPSY®-I tesztcsomag (Korkman, Kirk és Kemp, 1998) 27 szubtesztje 5 funkcióterület szerint csoportosul, melyek „nem feltétlenül azonosak a kognitív pszichológiában funkcionális egységnek tekintett megismerô rendszerekkel, sokkal inkább azonosak a fejlôdés-neuropszichológiában elterjedt kategóriákkal. A funkciók felosztása nem hasonlít azokhoz a szokásos tesztmodulokhoz sem, amelyeknek összetevôit faktoranalízis alapján alakították ki” (Csépe, Honbolygó és Surányi, 2007, 151; in Racsmány). Az 5 funkcióterület: Figyelmi/végrehajtó funkciók; Nyelv; Szenzomotoros funkciók; Téri-vizuális funkciók; Tanulás és emlékezet. Egy-egy feladat nem tartozik csupán egyetlen funkcióterülethez, több kategóriát is érinthet, a teljesítmény meghatározó komponensei a szubteszteredmények komplex elemzésével tárhatók fel (Csépe, 2007; in Racsmány).

7 A kialakított feladatsor esetén a tesztek (WISC-IV) koncepciójából tükrözôdnek a fluid gondolkodást, és a munkamemóriát mérô szubtesztek, melyek mind a vak gyermekek, mint a látó kontrollcsoport számára alkalmasak.

${ }^{8}$ Vak tanulók esetén az adatok a Fôvárosi Pedagógiai Szakszolgálat Látásvizsgáló, Gyógypedagógiai Tanácsadó, Korai Fejlesztô, Oktató és Gondozó Tagintézménye Szakvéleményeibôl származnak. 
kontrollcsoportokból - áll. A mintánk nem, életkor, VQ, gesztációs hét és születési súly szerinti illesztése megfelelőnek mondható.

A vizsgálat vak tanulók esetén a Vakok Általános Iskolájában ${ }^{9}$, a Gyengénlátók Általános Iskolájában ${ }^{10}$, a Kettesy Iskolában ${ }^{11}$, az integrációban tanuló gyermekek esetén otthonukban történt. Ôk a vizsgálat idején az 1995 és 2006 között született hazai, teljes, ép értelmú (VQ>85) iskoláskorú populációt képviselték. A feladatok felvétele 2010-2013 között zajlott. A látó kontroll vizsgálata az iskolájukban, otthonukban, koraszülött gyermekeknél alkalmanként a I. sz. Szülészeti és Nôgyógyászati Klinikán történt. A vizsgálatokat az adatvédelmi elốíásoknak megfelelően a szülők és tanulók tájékoztatásával és beleegyezésével végeztük.

A minta homogenitásának megórzése érdekében a vizsgálathoz nem használtuk fel egy 7 éves vak-koraszülött fiú eredményeit (VQ=145). A vizsgálatból kizártunk minden olyan vak tanulót, akinek Szakértôi véleményében ${ }^{12}$ a súlyos tanulási, figyelemvagy magatartásszabályozás zavar, illetve az autizmus spektrum zavar diagnózis szerepel, vagy aki a CBCL gyermekviselkedési kérdôív (Rózsa, Gádoros és Kô, 1998) szülôi vagy tanári változata alapján, a figyelemskálán 70 fölötti tértéket ért el. A Látásvizsgáló adatbázisából származó adatok szerint az általános iskoláskorú ép értelmú vak populációból (N=134) a kizáró tényezô miatt 3 gyermek, illetve 1 integrációban tanuló gyermek szülối beleegyezés hiánya miatt nem vett részt a vizsgálatban.

\section{Vizsgálati eszköz}

\section{Emlékezeti funkció}

Magyar Álszóismétlési Teszt (MÁT) (Racsmány és mtsai, 2005)

A fonológiai hurok mérésére szolgáló magyar álszóteszt 36 értelmetlen szóból áll (1-9 szótag), minden szótaghosszúsághoz 4 magyar fonológiájú álszó tartozik. A v.sz. álszóterjedelmét az a szótag hosszúság fogja kijelölni, amelyik álszavaiból legalább kettôt helyesen ismételt meg.

Számterjedelem Teszt (SZT) (Racsmány és mtsai, 2005)

A tesztet eredetileg Jacobs (1887) dolgozta ki. A verbális munkamemória kapacitásának mérôeszköze. A feladatban a v.v. számsorozatokat olvas fel, melyeket a v.sz.-nek az elhangzás sorrendjében kell visszamondania. A személy rövid távú emlékezeti kapacitását az a sorozathosszúság adja meg, amelybôl legalább kettô számsorozatot helyesen mondott vissza.

${ }^{9}$ Vakok Óvodája, Általános Iskolája, Speciális Szakiskolája, Egységes Gyógypedagógiai Módszertani Intézménye, Diákotthona és Kollégiuma.

${ }^{10}$ Gyengénlátók Általános Iskolája, Egységes Gyógypedagógiai Módszertani Intézménye és Kollégiuma.

${ }^{11}$ Hajdú-Bihar Megyeri Általános Iskola és Kollégium Dr. Kettesy Aladár Általános Iskola Intézményegység.

${ }^{12}$ A tanulók a Fôvárosi Pedagógiai Szakszolgálat Látásvizsgáló, Gyógypedagógiai Tanácsadó, Korai Fejlesztô, Oktató és Gondozó Tagintézménye által kiállított és hitelesített Szakértối Véleménnyel rendelkeznek, ahol jelölve van a látássérülés mellett megjelenô egyéb fogyatékosságtípus is. 
Fordított Számterjedelem Teszt (FSZT) (Janacsek és mtsai, 2009)

A számterjedelem teszthez hasonló mérôeljárás, mely fơleg a központi végrehajtó mûködésének kapacitását méri. A számokat az elhangzásukkal ellentétes sorrendben, viszszafelé kell elismételni.

Hallási Mondatterjedelem Teszt (HMT) (Swanson és Sachse-Lee, 2001)

A komplex verbális munkamemória mérésére alkalmas feladatsor, mely során a verbális információ rövid ideig tartó tárolása, aktívan tartása és manipulálása történik. A v.v. felolvas egy mondatot, amelyrôl a v.sz.-nek meg kell állapítania, hogy igaz-e, vagy hamis, valamint meg kell jegyeznie az utolsó szót. Amikor az adott blokkon belül az összes mondat elhangzott, a v.sz.-nek a mondat utolsó szavait kell megismételni az elhangzás sorrendjében. A feladat eredményét adott sorozaton belül az utolsó helyesen visszamondott blokk mondatainak száma adja, a végsô értéket pedig a három sorozat átlaga. A teszt magyar standardját Janacsek és munkatársai (2009) készítették el.

\section{Téri feldolgozás}

„Lapos-baba” mentális rotációs feladat (LB) - a szerzók által kidolgozott feladat

Az eszköz egy taktilisan és vizuálisan is könnyen felismerhető és a háttértôl elkülönüló sematikus ember(baba)figura (referenciapont a 2 kiemelkedô taktilis ponttal - szemek - megtámogatott fej).

A próba kétféle feladatot tartalmaz két különbözô helyzetú bemutatással. Az elsô feladatban a baba kezében lévô labda helyzetét kell felismerni (jobb vagy bal kezében van-e a labda), a másodikban a v.sz. által kiválasztott (baba) karra kell ráhelyezni a különbözô szögú forgatásokkor a labdát. A bemutatás kétféleképpen történik: mindkét feladat esetén a v.sz. elôször a teste előtt, azzal párhuzamosan tartott eszközön végzi el a feladatot, másodszor az asztalra téve, ami így a saját testéhez képest tükörképi helyzetbe kerül.

„A” feladat: a baba kezében lévô labdát a v.v. helyezi el. Az eszközt a v.sz. teste elôtt tartja különbözó forgatási szögekben. A feladat annak a kéznek a megnevezése, ahol a labda található.

Megnevezési feladat.

„B” feladat: az „A” feladattal megegyezik, de a feladat végrehajtása egy asztalon történik, a v.sz.-hez képest „tükörképes” helyzetben.

„C" feladat: az elsô, „álló” helyzetú figurán a v.sz. által kiválasztott babakézre kell ráhelyezni a labdát a forgatások során. Felismerési feladat.

„D” feladat: a „C” feladattal megegyezik, de a feladat végrehajtása egy asztalon történik, a v.sz.-hez képest „tükörképes” helyzetben.

A feladat pontosságot és sebességet mér. „Cipô” feladat $(C F)$ - a szerzók által kidolgozott feladat

A feladat ötletét a Kéz mentális rotációs teszt (Bonda, Petrides, Frey és Evans, 1995) adta. A próba során egy jobb és egy bal lábas csizmáról kell különbözô forgatási helyzetekben eldönteni, hogy bal vagy jobb lábas. A feladat maximálisan támaszkodik a saját test aktuális pozíciójára utaló információkra, továbbá az egocentrikus referencia- 
keretre, melyet a mentális rotációs feladat során a döntés, illetve a forgatás folyamata nagymértékben megnehezít.

Nyelvi funkció

Gyors megnevezés (RAN) - NEPSY $Y^{\circledR}$ feladata (a teszt kutatási célokra kialakitott magyar változata - Csépe, Honbolygó és Surányi, 2007) (látássérült gyermekek számára adaptálva)

Az idókorlátos próba az ismétlôdó taktilis felszínek, méretek és formák nevének gyors elérését és produkcióját vizsgálja. A feladat az alakzatok összes tulajdonságának megnevezése. A feladat együtt méri a folyamatos megnevezéshez szükséges funkciókat: a lexikonhoz való hozzáférés pontosságát, sebességét; a szekvencia fenntartását; a figyelmet; a taktilis követést. A gyenge teljesítmény hátterében gyors, de pontatlan, impulzív feladatvégzés, illetve csökkent feldolgozási sebesség is állhat.

Verbális fluencia $(V F)$ - a NEPSY ${ }^{\circledR}$ feladata (a teszt kutatási célokra kialakitott magyar változata - Csépe, Honbolygó és Surányi, 2007)

A próba a gyermek szógenerálási képességét vizsgálja, szemantikai (kategória) és fonológiai (fonéma) fluenciát mér. A v.sz.-nek - 4x60 másodperc alatt - a szemantikai fluencia feladatban állatokat, valamint ételeket és italokat kell megnevezni, a fonológiai fluencia feladatokban két eltérô mássalhangzóval kezdôdő szavakat kell felsorolni. A munkamemória központi végrehajtó funkcióját, a szókincs nagyságát, a szavakhoz való hozzáférést is teszteli.

Fonológiai feldolgozás (FF) (a teszt kutatási célokra kialakitott magyar változata - Csépe, Honbolygó és Surányi, 2007)

A feladat a fonológiai szegmentációt a szószegmensek (szótagok) és a hangok (fonémák) szintjén vizsgálja, és értékeli a fonológiai szegmentációt. A v.sz.-nek új szót kell képeznie úgy, hogy kihagy egy szószegmenst vagy egy hangot (fonológiai törlési feladat), illetve kicserél egy fonémát egy adott szóban (fonológiai csere feladat). A gyenge teljesítmény a sérült fonológiai feldolgozás, a hallási fonológiai észlelés és elemzés sérülését tükrözi. A teljesítményt befolyásolhatja a figyelem és/vagy a verbális munkamemória gyengesége is.

\section{Eljárás}

A vizsgálatban használt szubtesztek összehasonlítása céljából a feladatok nyerspontszámait a kontrollcsoport átlaga és szórása alapján standardizált z-score-okká alakítottuk át.

A statisztikai próbák előtt ellenôriztük a normalitás, szóráshomogenitás teljesülését, az adott próbák specifikus követelményeit. Az alkalmazott szubtesztek faktorelemzéssel három dimenzió mentén besorolásra, illetve összevetésre kerültek a teljes mintára nézve, továbbá a látó és a vak populációs adatokkal. Ez a faktorszerkezet az átfogó módszer validitásának becslését is szolgálja. 
A saját feladatok reliabilitása és validitása megfelelônek bizonyult, így a vizsgálatban felhasználásra kerülhettek. A nem megfelelô faktorsúly miatt az eredeti feladatsorból két feladatot kizártunk, így az elemzések során 16 összesített változóval számoltunk.

A csoportok összehasonlítása kétmintás $t$-próbával, az alcsoportok összehasonlítása többváltozós varianciaanalízissel, illetve kovarianciaanalízissel történt. A csoportok közötti különbségek megállapítására a posthoc elemzések közül a Tukey-próbát alkalmaztuk.

A statisztikai elemzéseket PASW Statistics 18 - SPSS programcsomaggal végeztük.

\section{EREDMÉNYEK}

\section{A feladatok faktorszkórjai}

A megerôsítô faktorelemzéssel (Confirmatory factor analysis) arra kerestük a választ, hogy a szubtesztek hány latens dimenziónak feleltethetôek meg, és a modell mennyire illeszkedik a látó és a vak mintára.

A modell illeszkedési mutatói elfogadhatóak (CFI és AGFI > 0.90, RMSE < 0.08), vagyis a szubtesztek 3 látens dimenziót alkotnak.

Fôkomponens-elemzés Varimax rotációval magyarázott variancia vakoknál az összvariancia 56\%-át, míg látóknál az 57\%-át magyarázza a teljes varianciának.

$\mathrm{CFI}=0,976$

AGFI $=0,905$

$\operatorname{RMSEA}=0,067(\mathrm{p}=0,19)$

A Hallási Mondatterjedelem Teszt, a Verbális fluencia feladat és a Gyors megnevezés feladat a vak és a látó csoport esetén is, mindhárom dimenziónak megfeleltethetốek. A téri feladatok mindegyike része a figyelem, végrehajtó funkciók látens dimenziójának.

\section{További eredmények}

\section{Emlékezet}

Az összehasonlító statisztika (kétmintás $t$-próba, vagy Welch-féle $d$-próba) két esetben jelzett statisztikailag szignifikáns eltérést a vak és a látó csoport között. A Magyar Álszóismétlési Teszt (MÂT) esetén a vak v.sz.-ek szignifikánsan magasabb eredményt értek el, mint a látók. A két csoport közötti különbség nagyságának becslésére a Cohen-féle hatásméret mutatót $(\mathrm{d})$ számítottuk ki. A MÁT feladat esetén a hatásméret nagyon magas $(1,414)$.

Az egyes feladatok belsố konzisztenciáját becslő Cronbach-alfa mutatók, minden feladat esetében az optimális tartományba esnek: 0,73-0,84.

A feladatok összevetésekor a Számterjedelem és Fordított Számterjedelem ( $\mathrm{r}=0,73$, $\mathrm{p}<0,001)$, illetve a Hallási Mondatterjedelem Teszt között $(\mathrm{r}=0,62, \mathrm{p}<0,001)$ láthatjuk a legszorosabb pozitív együttjárásokat. 


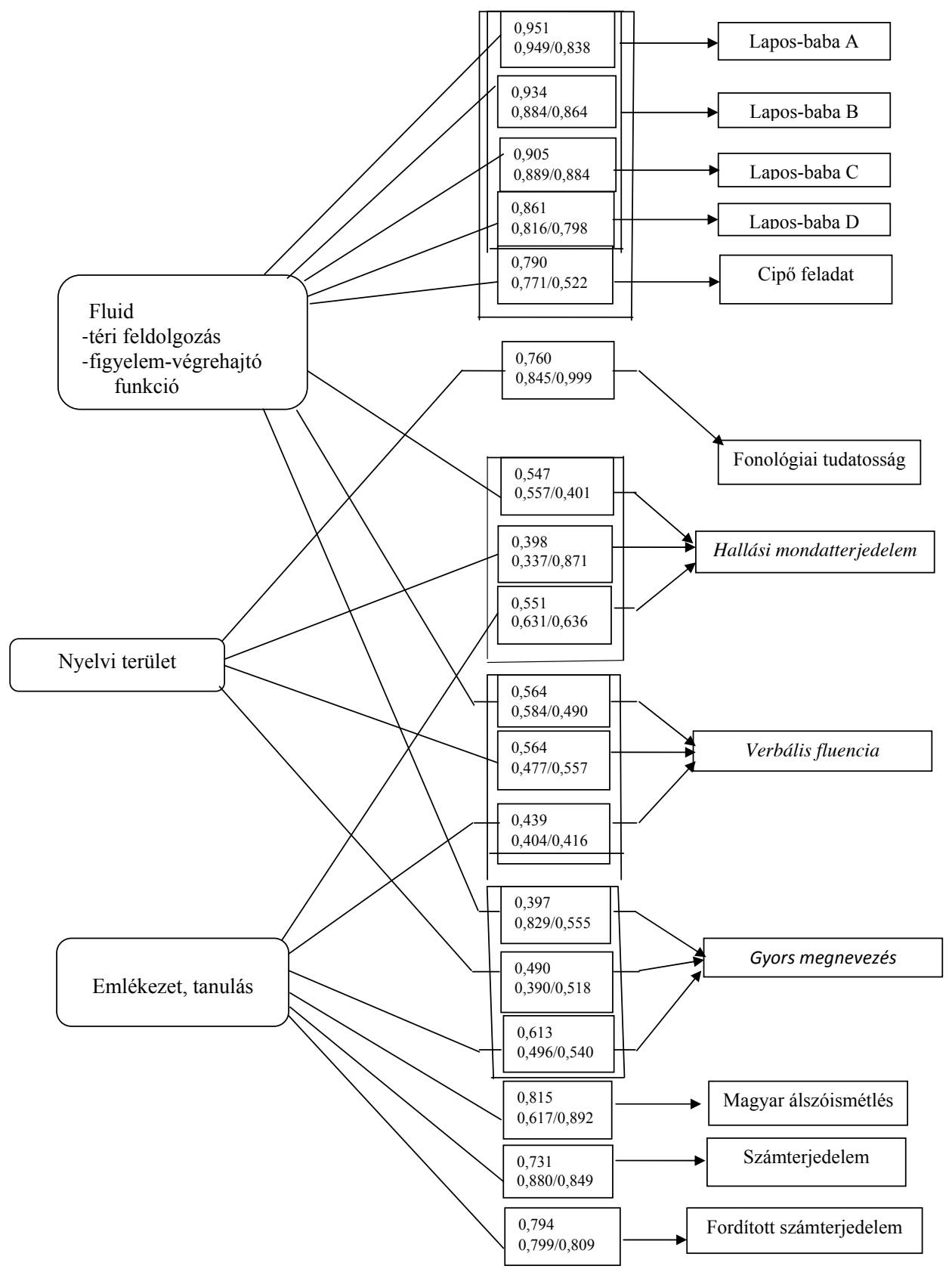

1. ábra. A feladatsor faktorszerkezete 


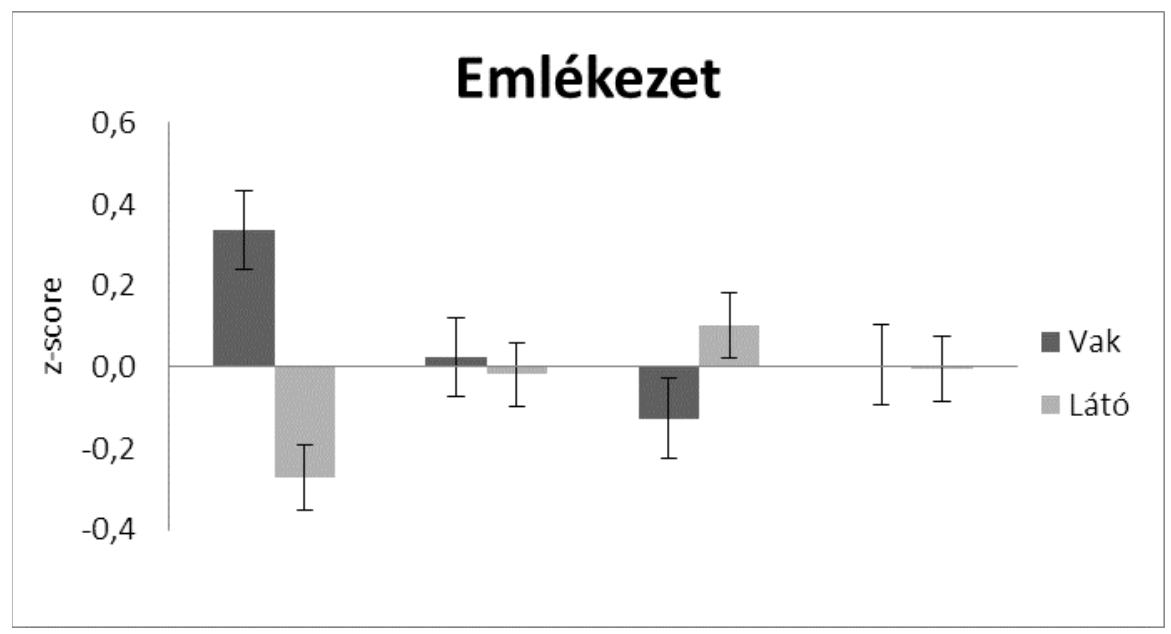

2. ábra. A verbális munkamemória feladatok összehasonlítása z-értékek mentén a két csoport esetén. A vak és a látó csoportok teljesítményátlagai a Magyar Álszóismétlési Teszt eredményeiben térnek el egymástól szignifikánsan. (MÁT: Magyar Álszóismétlési Teszt, SZT: Számismétlési Teszt, FSZT: Fordított Számismétlési Teszt, HMT: Hallási Mondatterjedelem Teszt. Az y-hibasávok a standard hibát jelzik)

A teljes mintán a vak és a látó csoportok munkamemória-feladatok közül kétmintás t-próbával mérve csak a Magyar Álszóismétlési Teszt $(\mathrm{t}(258)=-5,402, \mathrm{p}<0,001)$ eredményeinek átlagai térnek el egymástól szignifikánsan.

A MÁT feladat esetén a négy - gesztációs idő és látás alapján kialakított - csoport vizsgálata két szempontos varianciaanalízissel (ANCOVA) történt, ahol a VQ-t kovariánsként kezeltük. A látás $(\mathrm{F}(1)=43,15, \mathrm{p}<0,001)$ fơhhatása szignifikáns, a koraszülöttségé nem $(\mathrm{F}(1)=0,269, \mathrm{p}=0,604)$, azonban a két változó interakciója igen $(\mathrm{F}(1)=6,527$, $\mathrm{p}<0,05)$. A koraszülött csoportok gyengébben teljesítettek idôre született társaikhoz képest; a vak csoportok szignifikánsan jobb eredményt értek el a látó csoportokkal összehasonlítva. A kiegészítô post hoc analízis (Tukey HSD) szerint a VK-LI csoport $(\mathrm{F}(3)=11,596, \mathrm{p}<0,01)$, a VI-LK csoport $(\mathrm{p}<0,01)$, a VI-LI csoport $(\mathrm{p}<0,001)$ teljesítménye szignifikánsan különbözik egymástól.

Életkori bontás után külön elemzésre kerültek a 7;0-8;11, a 9;0-10;11 és a 11;0-15 éves életkori klaszter eredményei. Kétmintás $t$-próba eredménye alapján a vak gyermekek 9 éves korukban kezdenek el a látókhoz képest szignifikáns módon jobb eredményt elérni $(\mathrm{t}(47)=-4,934, \mathrm{p}<0,001)$, mely elôny a további életkori sávban megmarad $(\mathrm{t}(137)=-5,754, \mathrm{p}<0,001)$. A vak csoportokon belül tendenciaszerúen a VI csoport teljesít jobban. Látó gyermekeknél egy elgondolkodtató eredményt találtunk. Tendenciaszerúen ennél a feladatnál 7-9 évesen a koraszülött gyermekek jobb eredményt érnek el idôre született társaikhoz képest, majd előnyüket elvesztik. Feltételezzük, hogy az eredmény magyarázható a koraszülött gyermekek nagyarányú és széles spektrumú fejlesztésével, így a feladattal egy túltanult funkciót mértünk.

A SZT $(\mathrm{F}(2,8)=7,412, \mathrm{p}<0,1)$ és a FSZT $(\mathrm{F}(2,6)=4,352, \mathrm{p}<0,1)$ esetén a 4 csoport azonos eredményt ért el. Bár az eredmény nem szignifikáns, azonban tendencia jelleg- 


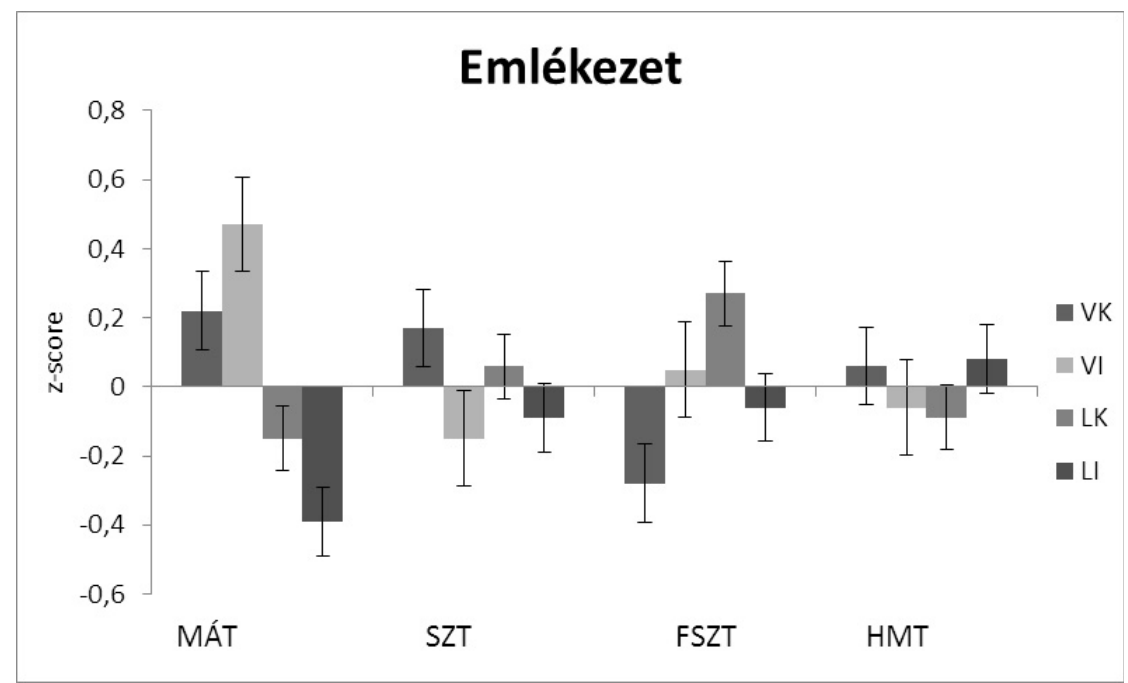

3. ábra. A verbális munkamemória feladatok összehasonlítása z-értékek mentén a négy csoport esetén. A Magyar Álszóismétlési Teszt feladataiban a koraszülött csoportok gyengébben teljesítettek idôre született társaikhoz képest; a vak csoportok szignifikánsan jobb eredményt értek el a látó csoportokkal összehasonlítva. (MÁT: Magyar Álszóismétlési Teszt, SZT: Számismétlési Teszt, FSZT: Fordított Számismétlési Teszt,

HMT: Hallási Mondatterjedelem Teszt, VK: vak koraszülött csoport, VI: vak idôre született csoport,

LK: látó koraszülött csoport, LI: látó időre született csoport. Az y-hibasávok a standard hibát jelzik)

gel megfigyelhetô, hogy a vak gyermekek 9 éves korukig azonos eredményt érnek el a látókéval $(\mathrm{t}(47)=4,371, \mathrm{p}<0,1)$, majd 9 éves kortól kezd a számterjedelmük magasabbá válni a látókéhoz képest $(\mathrm{t}(137)=4,516, \mathrm{p}<0,1)$.

A komplex munkamemóriát mérô HMT esetén a négy csoport eredménye között nem találtunk szignifikáns eltérést. Életkori bontás után azonban ennél a feladatnál is 9 éves kortól a vak gyermekek a látókéhoz képest jobb eredményt érnek el.

\section{Téri feldolgozás}

A feladatok minden esetben szignifikánsan eltérnek a vak és a látó csoport között. A Cronbach-alfa mutatók minden feladatnál az optimális tartományba esnek: $0,86-0,93$.

„Lapos-baba” mentális rotációs feladat (LB), „Cipô” feladat (CF)

A vak csoport a téri feldolgozás területén nagymértékú elmaradást mutat a látó kontrollhoz képest: LB (A: p<0,05; B: p<0,001; C: p<0,05; D: p<0,001), CF: p<0,01). A különbség a tükörképes elrendezések esetén kifejezettebb.

A kovarianciaelemzés (MANCOVA) eredménye szerint a LB(A) feladatban a látásnak nincs szignifikáns fôhatása, azonban a koraszülöttség $(\mathrm{p}<0,001)$ hatása, továbbá a két faktor interakciója is szignifikáns $(\mathrm{p}<0,01)$; a $\mathrm{LB}(\mathrm{B}),(\mathrm{C})$ és (D) feladatokban 


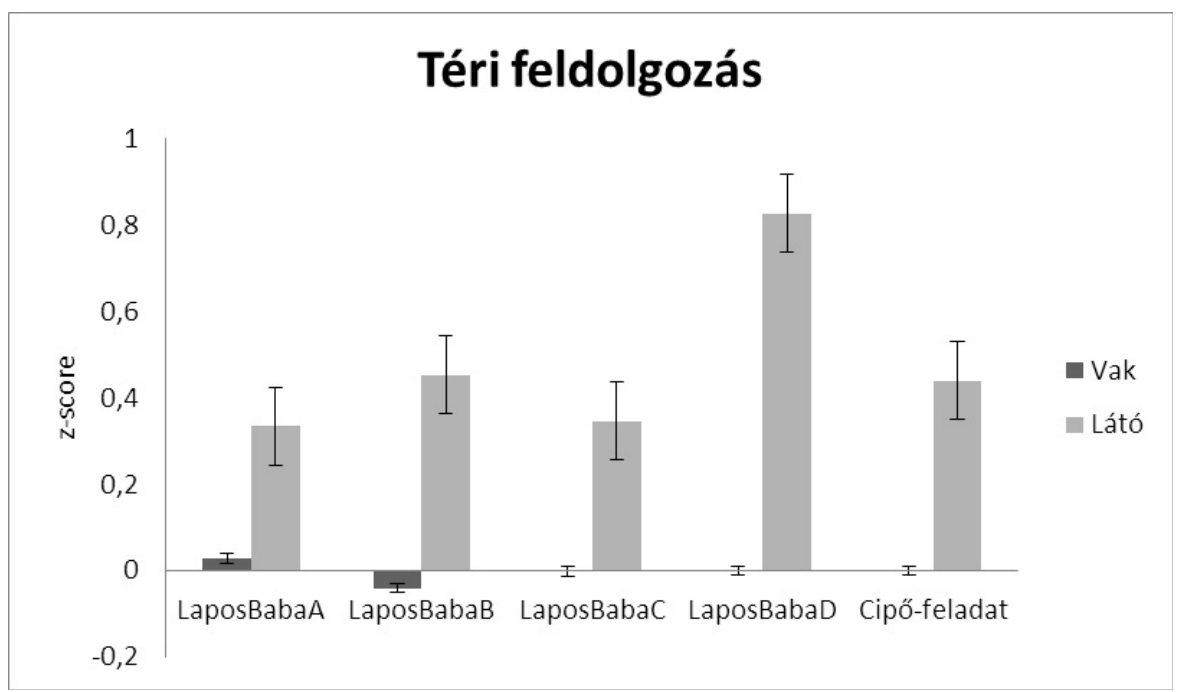

4. ábra. A téri feldolgozás feladatok összehasonlítása z-értékek mentén a két csoport esetén. A vak csoport a téri feldolgozás területén nagymértékú elmaradást mutat a látó kontrollhoz képest, mely kifejezettebb a tükörképes elrendezés esetén. (Az y-hibasávok a standard hibát jelzik.)

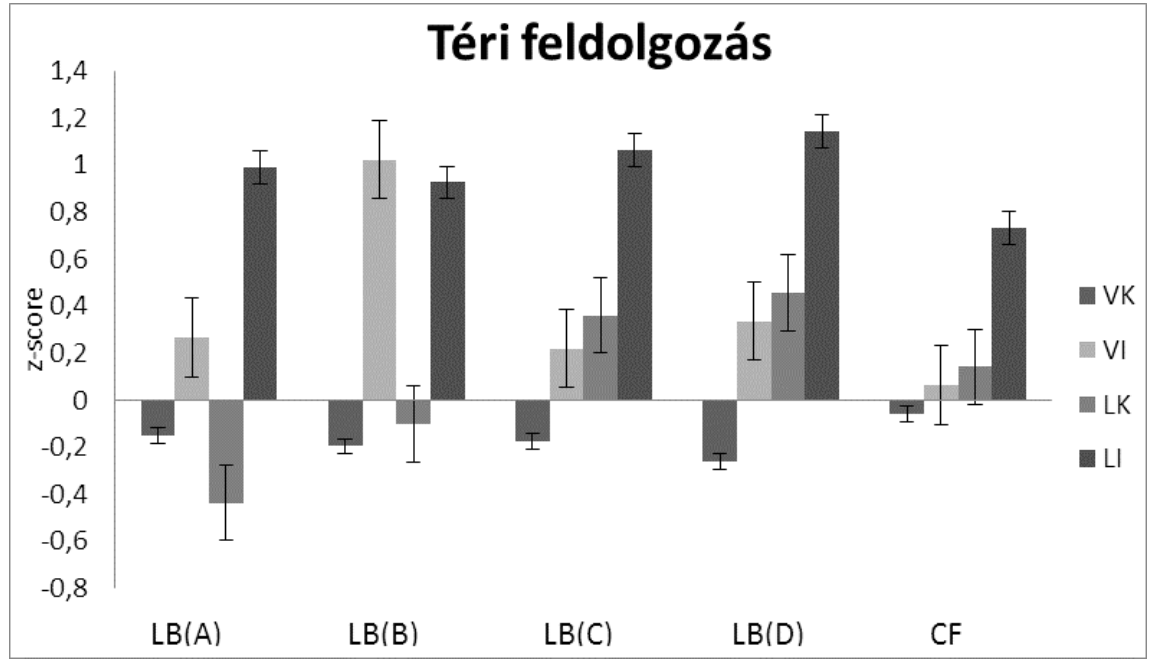

5. ábra. A téri feldolgozás feladatok összehasonlítása z-értékek mentén a négy csoport esetén. A vak csoport eredménye nem válik szét koraszülöttség alapján, azonban az (A) és a (C) feladatok esetén a látó csoportnál találunk szignifikáns eltérést a koraszülött és az idôre született v.sz.-ek között.

(LB: Lapos-baba feladat, CF: Cipó-feladat, VK: vak koraszülött csoport, VI: vak idôre született csoport, LK: látó koraszülött csoport, LI: látó idôre született csoport. Az y-hibasávok a standard hibát jelzik.) 


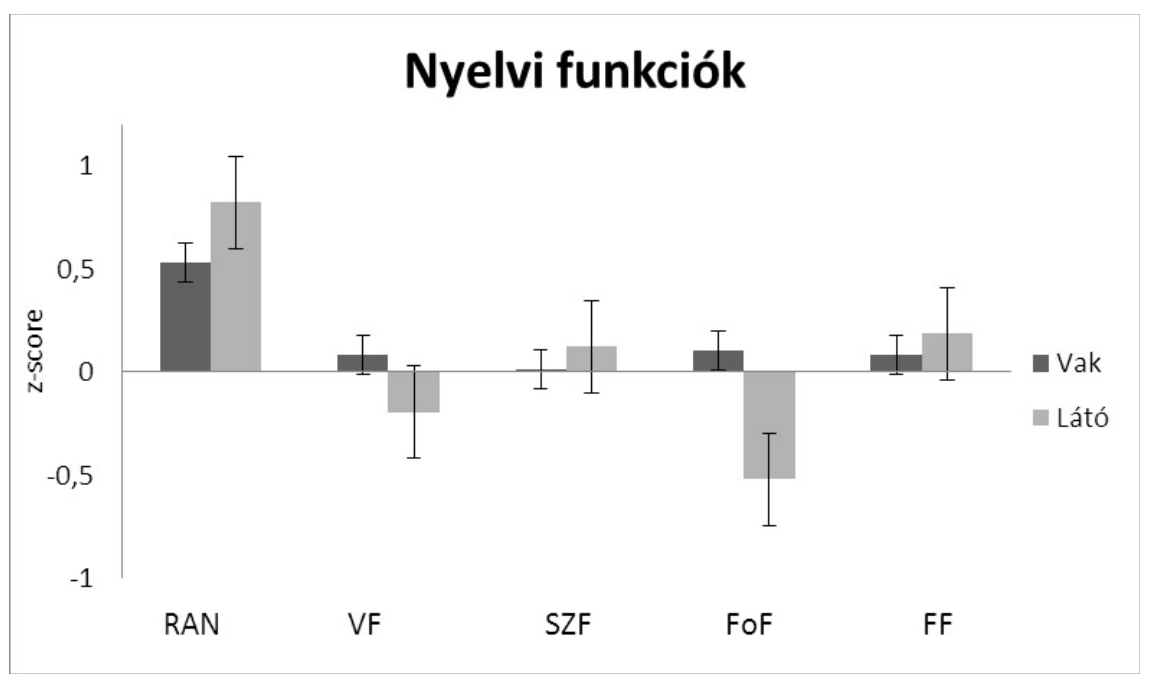

6. ábra. A verbális munkamemória feladatok összehasonlítása z-értékek mentén a két csoport esetén. A vak és a látó csoportok mutatói szignifikánsan Fonéma fluencia feladatban térnek el.

(RAN: Gyors megnevezés, VF: Verbális fluencia, SZF: Szemantikus fluencia, FoF: Fonéma fluencia, FF: Fonológiai feldolgozás. Az y-hibasávok a standard hibát jelzik.)

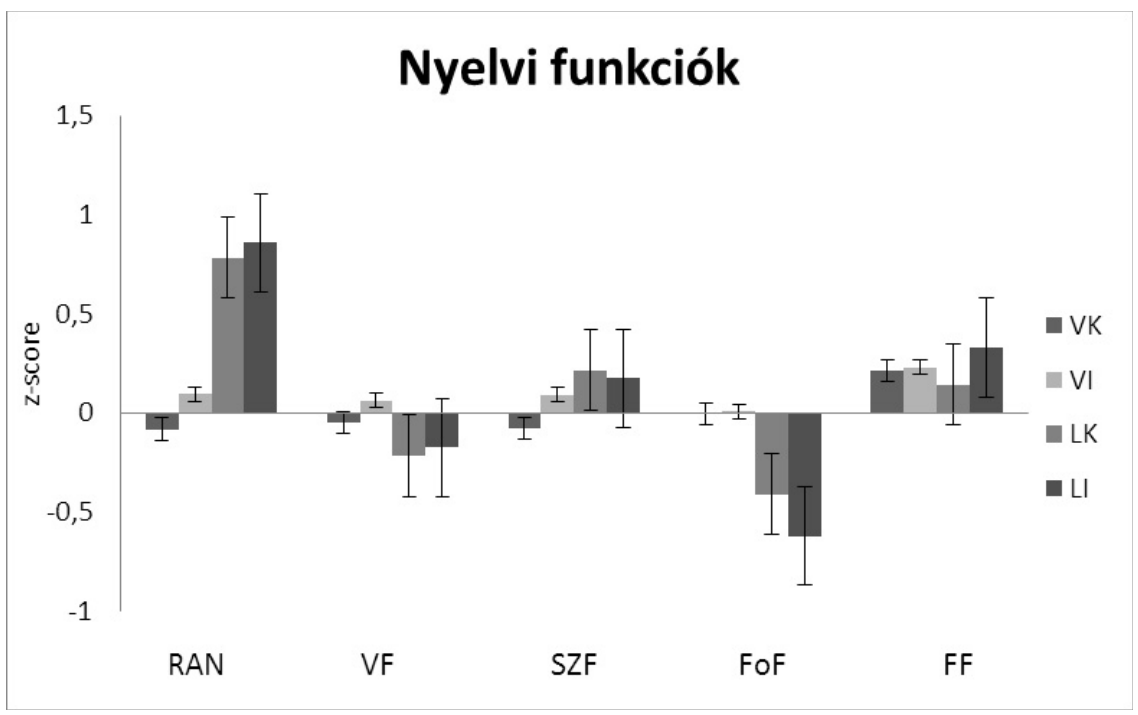

7. ábra. A verbális munkamemória feladatok összehasonlítása z-értékek mentén a négy csoport esetén (RAN: Gyors megnevezés, VF: Verbális fluencia, SZF: Szemantikus fluencia, FoF: Fonéma fluencia, FF: Fonológiai feldolgozás, VK: vak koraszülött csoport, VI: vak idôre született csoport, LK: látó koraszülött csoport, LI: látó idôre született csoport. Az y-hibasávok a standard hibát jelzik.) 
mind a látás, mind a koraszülöttség változónak szignifikáns a foohatása, továbbá a két faktor interakciója is szignifikáns.

A kiegészítô post hoc analízis (Tukey HSD) szerint a vak csoport esetén nem válik szét koraszülöttség alapján az eredmény, azonban az (A) és a (C) feladatnál a látó csoportnál találunk szignifikáns eltérést $(\mathrm{p}<0,001)$ a koraszülött és az időre született v.sz.-ek között. A két feladat végzése a saját testtel párhuzamos módon történik, amely feladatelrendezéssel ritkán találkoznak a látó gyermekek, így ez a - nem túltanult - feladat bizonyul a két csoport között diszkrimináló hatásúnak.

A „Cipô” feladatban (CF) a látás $(\mathrm{F}(1)=10,254, \mathrm{p}<0,01)$ és a koraszülöttség is $(\mathrm{F}(1)=6,942, \mathrm{p}<0,01)$ szignifikáns fớhatással rendelkezik, a két változó interakciója tendencia jellegú $(\mathrm{F}(1)=2,979, \mathrm{p}=0,086)$.

A post hoc analízis során szintén a LK-LI $(\mathrm{p}<0,01)$ csoportok között találtunk szignifikáns eltérést.

\section{Nyelvi funkció}

A vak és látó csoportok esetén csak a Fonológiai fluencia feladat esetén találtunk szignifikáns eltérést. A két csoport közti különbség nagysága közepes méretú (d: 0,68). A Cronbach-alfa mutatók az optimális tartományba esnek: 0,71-0,82.

A vak és a látó csoportok mutatói szignifikánsan csak a Fonéma fluencia (FoF) feladatban térnek el $(\mathrm{t}(289)=-5,255, \mathrm{p}<0,001)$.

A kovarianciaanalízis alapján a Fonéma fluencia (FoF) feladatban a látás szignifikáns foohatású $(\mathrm{F}(1)=27,291, \mathrm{p}<0,001)$, azonban a koraszülöttség nem. Itt a vakon született csoport egyedi, „vakspecifikus” szókeresési stratégiája figyelhetô meg. Ezt támasztja alá, hogy a VK-VI csoport között nincs különbség $(p<0,99)$.

A feladat során a legrosszabb teljesítményt a VI csoport érte el.

\section{MEGBESZÉLÉS}

Kutatásunk célja a korábban és jelenleg is használt populációspecifikus tesztbatériák bemutatásán túl, egy általunk kialakított és pszichometriai elemzésnek alávetett feladatsor használatával 7-15 éves teljes magyar ép értelmú vak populáció és illesztett látó kontrollcsoport felmérése, és kognitív profiljának elemzése. Egy olyan feladatsor kialakítására törekedtünk, amely mind látó, mind látássérült személyek részére megfelelô, továbbá mind verbális, mind performációs szubteszteket tartalmaz. Három alapterület - emlékezet, tanulás; téri feldolgozás; nyelvi terület - vizsgálata történt. Igyekeztünk feltárni vak gyermekeknél az átlagos kognitív kapacitás mellett is az egyes megismerési funkciók lényeges eltéréseit. A vak csoportot gesztációs idô szerint két alcsoportra bontottuk, melyet figyelme vettünk a kontrollcsoportok illesztésekor.

Az eredményeink alapján Bliss, Kujala és Hamalainen (2004) vizsgálataihoz hasonlóan nem találtunk a vakon született gyermekeknél, a látókhoz viszonyítva jelentôs mértékben (Smits és Mommers, 1976) jobb kognitív képességeket, beleértve a rövid távú (Hull és Mason, 1995) és hosszú távú memóriát (Amedi és mtsai, 2003; Röder és Rösler, 2003). 
Dekker (1989) kiemeli, hogy a vakon született gyermekek verbális memóriára épülô feladatokban jobb eredményt érnek el, mint a látó, a késôbb megvakult és az aliglátó gyermekek. Álláspontjuk szerint a jobb memória teljesítmények oka, hogy a vak személyek hatásosabban kódolják az auditív verbális információkat (pl. Röder, Rösler és Neville, 2001). A munkamemória-feladatok eredményeinek elemzésekor a vak csoportok elônyét vártuk a látókkal szemben Röder és Neville (2003), illetve Hötting és Röder (2009) vizsgálataira alapozva, akik rámutattak arra, hogy az akusztikusan bemutatott szavakkal és számokkal végzett feladatok esetén, a vakon született vizsgálati személyeknek „kifejezetten” magasabb a munkamemória kapacitásuk. Úgy gondoltuk továbbá, hogy mind a vak, mind a látó csoportoknál a koraszülöttség ténye negatív módon befolyásolja a teljesítményt. A központi végrehajtó múködést mérố Fordított Számterjedelem és Hallási Mondatterjedelem Teszt közötti szoros együttjárás nem meglepó, azonban a Számterjedelem és Fordított Számterjedelem együttjárását nem vártuk, helyette a fonológiai hurok mérésére alkalmas Magyar Álszóterjedelem és Számterjedelem feladatok közti magas kapcsolati mutatóra számítottunk. Vizsgálatunk során a vak és a látó csoportok a munkamemória feladatok közül csak a Magyar Álszóismétlési Teszt esetén mutattak szignifikáns különbséget. Az idôre született vak gyermekek szignifikánsan jobban teljesítettek a feladatban, mint az időre született látó kontrollcsoport. Eredményünk szerint az időre született vak csoport verbális munkamemóriája, fonológiai hurok kapacitása nagyobb, mint a látóknak. Ugyanezt az eredményt figyelhetjük meg, ha a vak és a látó csoportokban mind a koraszülött, mind az idôre született vizsgálati személyek összeredményét vizsgáljuk. Vagyis a vak csoport nem teljesít a látó csoporthoz képest rosszabbul, ha a koraszülött vak gyermekek roszszabb eredménye is felhasználásra kerül az elemzés során.

A születéstôl fennálló látáshiány nem akadálya a téri-vizuális memóriafolyamatok és a mentális forgatás használatának, bár azok kezelése hosszabb idốt vesz igénybe a látássérült embereknél (Kerr, 1983). Cornoldi, Fastame és Vecchi (2003) hangsúlyozza, hogy ezt az idôi eltérést nem szabadna általánosan a vizualitás hiányából adódó hátrányként magyarázni, mivel az szerintük a vak személyek egyéni kognitív képességeiból származik.

Eredményeink alapján a vak gyermekek, életkoruktól függetlenül a téri feldolgozást mérô feladatokban, köztük a mentális forgatási feladatokban nagymértékben elmaradnak a látó kontroll csoporttól. A leíró jellegú referencia hipotézis modell (Millar, 2006) szerint a téri percepció nem tudatos logikai következtetés mentén történik, a forma- és térpercepció a kogníció által mediált. A téri feldolgozás a - bármely forrásból származó - input szervezése és integrálása, mely források referenciakeretként funkcionálnak, a hely, a távolság és az irány meghatározásakor.

A haptikus tér testközpontú (body-centered), egocentrikus referenciakeretú, míg a vizuális tér külsố koordináta központú. A taktilitás proximális, a vizualitás disztális szenzoros információkat tartalmaz. A saját test, mint vonatkoztatási keret, a vak személyek számára elengedhetetlen fontosságú. A saját testbôl származó információk úgymint a testközép, a fej, a vállak pozíciója, a nyúlás mozdulata, a tapintásos mozgás nagysága, kiterjedése - adják a referenciakeretet. Ezért a taktilitásra mint percepcióra nem csupán mint egy független folyamatra kell tekintenünk, hanem egy olyan komp- 
lex múveletre, mely a tapintáson, haptikus információk kódolásán túl, a saját testból származó téri információkat is tartalmazza. A haptikus információk téri kódolása a személy perszonális terében történik, mely radikálisan eltér a vizuális percepciótól, ami externális referenciakeretet használ (Millar, 1994, 2006).

A tér meghatározásának pontossága mind a vizuális, mind a taktilis modalitásban a referenciakeretek összehangolódásán alapszik, és nem az egyes modalitásokhoz csatlakozó specifikus „információtípusokon” (Millar, 2006).

Eredményeink szerint a téri feladatok sikerességében szerepe van a látásnak és a születési idônek. A vak csoport eredményesebben oldotta meg a saját testtel párhuzamosan végezhetô téri feladatokat, mint a tükörképes elrendezésúeket. Ennek oka szintén az, hogy a vak személyeknél a testközpontú információk elérhetôbbek, és sokkal megbízhatóbbak, mint az externális információk. A testközpontú téri kódolás arra utal, hogy a testet szisztematikusan, referenciakeretként használják a vak személyek a helyzetek és irányok meghatározásához (Millar, 1994). A vakon született gyermekeknek ezért folyamatos nehézségük van a tér megértésében és használatában (Rieser, 1992), így azokat a téri feladatokat, melyek elrendezése a gyermek testéhez képest tükörképesek, a vak vizsgálati személyek nem tudják kellóképpen a testközpontú téri kódolásra támaszkodva megoldani. A látó személyek a vizuális modalitásban történô, a saját testtôl kevésbé függô, externális információkat feldolgozó feladatmegoldás miatt nagymértékú előnyre tesznek szert.

Szintén nem meglepó eredmény, hogy a látó mintában a koraszülött gyermekek a téri feladatok esetén rosszabbul teljesítenek idôre született társaikhoz képest. Mindez összhangban van Györkő, Lábadi és Beke (2012) eredményeivel. A koraszülöttség ténye késleltetheti a téri viszonyok megismerését, a tér reprezentációjának kialakulását, mely hátrány még iskolás korban is megjelenik a téri feladatok esetén.

A nyelvi funkciót mérô feladatoknál a két csoport eredménye szignifikánsan csak a Fonéma fluencia (FoF) feladatban tért el egymástól. Itt a vakon született csoport egyedi, „vakspecifikus” szókeresési stratégiája figyelhetô meg, melyet nem befolyásol a születési idó.

Míg a kategóriák elôhívása azonos módon és mértékben történik a látó személyekhez viszonyítva, addig a fonémaalapú elôhívás, mint szótalálási stratégia, jobb eredményhez vezet. A szavak keresése tehát számukra könnyebb a fonémahangzás mint kategória szerint. Az eredményt megerôsíti Nejati és Asadi (2010) vizsgálata, akik 137 felnốtt korban (>20 év) megvakult személy esetén azonos Verbális kategóriafluencia és Verbális fonémafluencia eredményt találtak az illesztett látó kontrollcsoporttal való összehasonlítás során. A várt eredménnyel ellentétben, a fonológiai tudatosságot mérô feladatban a vak csoportok teljesítettek rosszabbul a látókhoz képest. A feltevésünk, miszerint a koraszülött csoportok lesznek kevésbé eredményesek, csak a látó csoportok esetében teljesült.

A kialakított feladatsorunk megfeleloonek bizonyult a két populáció mérésére, ezen kívül eredményesnek bizonyult a születési idô talaján kialakuló specifikus eltérések megjelenítésére is. Eredményeink összevethetôknek bizonyultak a korábbi irodalmi adatokkal. Munkánkkal szélesebb képet nyertünk a koraszülött és idốre született súlyos fokú látássérült gyermekek emlékezeti, nyelvi és téri képességeirôl. 


\section{Korlátok és kitekintés}

Eredményeinket a vizsgálat korlátaival együtt optimális elemezni. A vak mintába való beválogatás egy régi tesztbattéria alkalmazásával történt, csak a VQ mérésével. A dolgozatban nem tüntettük fel, de a VQ eredmények korreláltak a nyelvi és verbális emlékezeti feladatokkal, azonban a beválogatási szempontot egysíkúvá tette, mivel a vak vizsgálati személyek nem egy átfogó intellektuális képességvizsgálat után kerültek be a vizsgálati mintába.

Az emlékezeti feladatok esetén rendelkezünk hazai normákkal, melyekkel eredményeink összevetésre kerülhettek, több életkori sávban is. Kívánatos lenne a további normaértékekkel való összevetés lehetôsége.

Az alacsony mintaelemszám és a nagyszámú változó nem optimális a többváltozós elemzésekhez. Fontos azonban megjegyezni, hogy a vak mintánk az adott életkori sávban a teljes magyar ép értelmú vak populációt lefedte.

\section{IRODALOM}

Amedi, A., Raz, N., Pianka, P., Malach, R., \& Zohary, E. (2003). Early 'visual' cortex activation correlates with superior verbal memory performance in the blind. Nature Neuroscience, 6 , 758-66.

Ballesteros, S., Bardisa, D., Millar, S., \& Reales, J. M. (2005). The haptic test battery: a new instrument to test tactual abilities in blind and visually impaired and sighted children. British Journal of Visual Impairment 23(1), 11-24.

Begum, S. (2003). Cognitive Development in Blind Children. New Delhi: Discovery Publishing House.

Bertone, A., Bettinelli, L., \& Faubert, J. (2007). The impact of blurred vision on cognitive assessment. Journal of Clinical and Experimental Neuropsychology, 29(5), 467-476.

Bliss, I., Kujala, T., \& Hamalainen, H. (2004). Comparison of blind and sighted participants' performance in a letter recognition working memory task. Brain Research: Cognitive Research, 18(3), 273-277.

Boehm, A. E. (1971). Boehm Test of Basic Concepts: Manual. New York: Psychological Corporation.

Brady, S., Shankweiler, D., \& Mann, V. (1983). Speech perception and memory coding in relation to reading ability. Journal of Experimental Child Psychology, 35, 345-367.

Cornoldi, C., Fastame, M.C., \& Vecchi, T. (2003). Congenital blindness and spatial mental imagery. In. A. Hatwell, A. Streri, \& E. Gentaz (Eds), Touching for knowing (pp. 173-187). Amsterdam-Philadelphia: John Benjamins Publishing Company.

Crepeau-Hobson, F., \& Vujeva, H. (2012). Assessment of cognitive ability of students with severe and low-incidence disabilities. National Association of School Psychologists. Communiqué, 41(2), $12-13$.

Csépe V., Honbolygó F., \& Surányi Zs. (2007). Tapasztalatok a NEPSY ${ }^{\circledR}$ magyar nyelvú változatával, In Racsmány M. (2007) (szerk.), A fejlódés zavarai és vizsgálómódszerei (pp.148-170). Budapest: Akadémiai Kiadó.

Dekker, R., Drenth, P. J. D., \& Zaal, J. N. (1991). Results of the Intelligence Test for Visually Impaired Children (ITVIC). Journal of Visual Impairment and Blindness, 85(6), 261-267. 
Dekker, R. (1993). Visually impaired children and haptic intelligence test scores: Intelligence Test for Visually Impaired Children (ITVIC). Developmental Medicine E Child Neurology, 35, 478-489.

Dial, J., Mezger, C., Gray, S., Chan, R., \& Massey, T. (1991). Cognitive Test for the Blind and Visually Impaired. Dallas, TX: McCarron-Dial Systems, Inc. Vocational Evaluation and Work Adjustment Bulletin, 9, 24-33.

Dial, J., \& Dial, C. (2010). Assessing and intervening with visually impaired children and adolescents. In D. Miller (Ed.), Best practices in school neuropsychology: Guidelines for effective practice, assessment, and evidence-based intervention (pp. 465-479). Hoboken, NJ: Wiley.

Driver, L., \& Warschausky, S. (2010). Use of assistive technology in adapted cognitive assessment. 25th Annual International Technology \& Persons with Disabilities Conference, San Diego, CA.

Ek, U., Jacobson, L., Ygge, J., Fellenius, K., \& Flodmark, O. (2000). Visual and cognitive development and reading achievement in four children with visual impairment due to periventricular leukomalacia. Visual Impairment Research, 2(1), 3-16.

Fjeldsenden, B. (2000). Blindness and Cognitive Structures

http://www.sv.ntnu.no/psy/bjarne.fjeldsenden/Articles/CognitionandBlindness.htm

Györkô E., Lábadi B., \& Beke A. (2012). Téri viszonyok és a nyelvi reprezentáció a koraszülötteknél. Gyógypedagógiai Szemle, 40(2),106-121.

Hill, E. W. (1981). Hill Performance Test of Selected Positional Concepts. Wood Dale: Stoelting Company.

Hill-Briggs, F., Dial, J., Morere, D, \& Joyce, A. (2007). Neuropsychological assessment of persons with physical disability, visual impairment, or blindness, and hearing impairment or deafness. Archives of Clinical Neuropsychology, 22, 389-404.

Hötting, K., \& Röder, B. (2009). Auditory and auditory-tactile processing in congenitally blind humans. Hearing Research, 258(1-2), 165-174.

Hull, T. \& Mason, H. (1995). Performance of blind children on digit span tests. Journal of Visual Impairment Eं Blindness, 89(2), 166-169.

Jacobs, J. (1887). Experiments on "prehension". Mind, 12, 75-79.

Janacsek K., Tánczos T., Mészáros T., \& Németh D. (2009). A munkamemória új magyar nyelvú neuropszichológiai mérőeljárása: a Hallási Mondatterjedelem Teszt (HMT). Magyar Pszichológiai Szemle, 64(2), 385-406.

Kerr, N. H. (1983). The role of vision in „visual imagery” experiments: Evidence from congenitally blind. Journal of Experimental Psychology: General, 112, 265-267.

Korkman, M., Kirk, U., \& Kemp, S. (1998). NEPSY: A developmental neuropsychological assessment. San Antonio, TX: The Psychological Corporation.

Koustriava, E. (2010). Mental Rotation Ability of Individuals with Visual Impairments. Journal of Visual Impairment $\mathcal{E}$ Blindness, 104(9) 570-575.

Lezak M. D., Howieson D. B., Loring D.W., \& Hannay H. J. (2004). Neuropsychological Assessment (4th ed.). New York: Oxford University Press.

Li, S. C., Jordanova, M. \& Lindenberger, U. (1998). From good senses to good sense: A link between tactile information processing and intelligence. Intelligence, 26, 99-122.

Marmor, G. S, \& Zaback, L. A. (1976). Mental rotation by the blind: does mental rotation depend on visual imagery? Journal of Experimental Psychology. Human Perception and Performance, 2(4), 515-521.

McCarron, L., \& Horn, P. (1979). Haptic discrimination and intelligence. Journal of Clinical Psychology, 35, 117-120.

Millar, S. (1994). Understanding and representing space. Oxford: Oxford University Press. 
Millar, S. (2006). Processing Spatial Information From Touch and Movement: Implications From and for Neuroscience In M. A. Heller \& S. Ballesteros (Eds), Touch and Blindness - Psychology and Neuroscience (pp. 25-48). New Jersey: Lawrence Erlbaum Associates.

Miller, J. C., Skillman, G. D., Benedetto, J. M., Holtz, A. M., Nassif, C. L., \& Weber, A. D. (2007). A Three-Dimensional Haptic Matrix Test of Nonverbal Reasoning. Journal of Visual Impairment and Blindness, 101(9), 514-557.

Mommers, M. J. C. (1974). Toetsing van intelligentie en van de haptische waarneming bij blinde kinderen (Assessment of intelligence and haptic perception in blind children). Nijmegen: Instituut voor Onderwijskunde, Katholieke Universiteit Nijmegen. In R. Dekker, (1993). Visually impaired children and haptic intelligence test scores: Intelligence Test for Visually Impaired Children (ITVIC). Developmental Medicine $\mathcal{E}$ Child Neurology, 35, 478-489.

Nejati, V. \& Asadi, A. (2010). Semantic and phonemic verbal fluency in blinds. Journal of Psycholinguistic Research, 39(3), 235-242.

Nelson, P. A., Dial, J. G., \& Joyce, A. (2002). Validation of the cognitive test for the blind as an assessment of intellectual functioning. Rehabilitation Psychology, 47(2), 184-193.

Newland, T. E. (1964). Predictions and evaluations of academic learning by children. International Journal for the Education of the Blind 14, 1-7.

Nolan, C., Morris, Y., \& June, E. (1965). Development and Validation of the Roughness Discrimination Test. International Journal for the Education of the Blind,15, 1-6.

Prónay B. (2004). Vak gyermekek verbális intelligenciájának vizsgálata. Tapasztalatok a MAWGYI-R teszttel. Magyar Pszichológiai Szemle, 59(1), 57-75.

Prónay B. (2014) . Az „Intelligenciateszt Látássérült Gyermekek Számára” bemutatása és egy magyar minta eredményei. Magyar Pszichológiai Szemle 69(1), 145-162.

Racsmány M., Lukács Á., Németh D., \& Pléh Cs. (2005). A verbális munkamemória magyar nyelvú vizsgálóeljárásai. Magyar Pszichológiai Szemle, 60(4), 479-505.

Rieser, J. J., Hill, E. W., Talor, C. R., Bradfield, A., \& Rosen, S. (1992). Visual Experience, Visual Field Size, and the Development of Nonvisual Sensitivity to the Spatial Structure of Outdoor Neighborhoods Explored by Walking. Journal of Experimental Psychology, 121(2), 210-221.

Rózsa, S., Gádoros, J., Ē Kő, N. (1998). A Gyermekviselkedési Kérdỗu. ELTE, Budapest. Belsô Kiadvány.

Roid, G. (2003). Stanford-Binet Intelligence Scales, Fifth Edition: Interpretive manual. Itasca, IL: Riverside.

Röder, B., \& Neville, H. J. (2003). Developmental functional plasticity. In J. Grafman, \& I. H. Robertson (Eds), Plasticity and Rehabilitation (pp. 231-270). Amsterdam: Elsevier Science B.V.

Röder, B., \& Rösler, F. (2003). Memory for environmental sounds in sighted, congenitally blind and late blind adults: Evidence for cross-modal compensation. International Journal of Psychophysiology. 50, 27-39.

Röder, B., Rösler, F., \& Neville, H. J. (2001). Auditory memory in congenitally blind adults: A behavioral-electrophysiological investigation. Brain research. Cognitive brain research, 11, 289-303.

Sattler, J., \& Dumont, R. (2004). Assessment of children: WISC-IV and WPPSI-III supplement. San Diego, CA: Jerome M. Sattler.

Smits, B., \& Mommers, M. J. C. (1976). Differences between blind and sighted children on WISC verbal subtests. New Outlook Blind, 70, 240-246.

Swanson, H. L., \& Sachse-Lee, C. (2001) A subgroup analysis of working memory in children with reading disabilities: domain-general or domain-specific deficiency? Journal of Learning Disabilities, 34(3), 249-263. 
Tobin, M. J., \& Hill, E. W. (2011). Issues in the educational. psychological assessment of visually impaired children: Test-retest reliability of the Williams Intelligence Test for Children with Defective Vision. British Journal of Visual Impairment, 29(3), 208-214.

Withagen, A., Vervloed, M. P. J., Janssen, N. M., Knoors, H., \& Verhoeve, L. (2009). The Tactual Profile: Development of a procedure to assess the tactual functioning of children who are blind. British Journal of Visual Impairment, 27(3), 221-238.

\title{
MEMORY CAPACITY, LANGUAGE AND SPATIAL PROCESSES IN 7-15-YEAR-OLD BLIND CHILDREN
}

\author{
PAJOR, EMESE - BEKE, ANNA MÁRIA - CSÉPE, VALÉRIA
}

The cognitive investigation of visually impaired population poses difficulties due to the limitations of the methodology of measurement. This is especially so for blind children.

The goal of this paper is to present population specific tests are presented in the past as well as in the present. This is followed by the cognitive profile of the complete 7-15 year old blind (with typical development) population of Hungary as well as that of the matched sample sighted control group. The analyses have been carried out using a set of test questions developed and psychometrically tested by the present authors.

The case of the thus selected or newly created test questions is based on theoretical and practical experience derived from NEPSY®-I and WISC-IV tests.

According our results, the results on spatial tasks are influenced by vision and the time of birth. Among working memory tasks, there was significant difference only in the Hungarian non-word-repetition task, between the blind and the sighted groups. There was also a significant difference between the two groups in phonemic fluency task.

Spatial orientation is largely influenced by blindness but we have not found the same result in verbal working memory capacity and in language functions.

Keywords: blindness, cognitive profile, measurement methodological questions 